\title{
Rapid thinning of lake-calving Yakutat Glacier and the collapse of the Yakutat Icefield, southeast Alaska, USA
}

\author{
Barbara L. TRÜSSEL, ${ }^{1,2}$ Roman J. MOTYKA, ${ }^{1}$ Martin TRUFFER, ${ }^{1,3}$ \\ Christopher F. LARSEN ${ }^{1}$ \\ ${ }^{1}$ Geophysical Institute, University of Alaska Fairbanks, Fairbanks, AK, USA \\ E-mail: btruessel@gi.alaska.edu \\ ${ }^{2}$ Department of Geology and Geophysics, University of Alaska Fairbanks, Fairbanks, AK, USA \\ ${ }^{3}$ Physics Department, University of Alaska Fairbanks, Fairbanks, AK, USA
}

\begin{abstract}
Both lake-calving Yakutat Glacier $\left(337 \mathrm{~km}^{2}\right)$, Alaska, USA, and its parent icefield $\left(810 \mathrm{~km}^{2}\right)$ are experiencing strong thinning, and under current climate conditions will eventually disappear. Comparison of digital elevation models shows that Yakutat Glacier thinned at area-averaged rates of $4.76 \pm 0.06 \mathrm{~m}$ w.e. $\mathrm{a}^{-1}(2000-07)$ and $3.66 \pm 0.03 \mathrm{~m}$ w.e. $\mathrm{a}^{-1}$ (2007-10). Simultaneously, adjacent Yakutat Icefield land-terminating glaciers thinned at lower but still substantial rates (3.79 and $2.94 \mathrm{~m}$ w.e. $\mathrm{a}^{-1}$ respectively for the same time periods), indicating lake-calving dynamics helps drive increased mass loss. Yakutat Glacier terminates into Harlequin Lake and for over a decade sustained a $\sim 3 \mathrm{~km}$ long floating tongue, which started to disintegrate into large tabular icebergs in 2010. Such floating tongues are rarely seen on temperate tidewater glaciers. We hypothesize that this difference is likely due to the lack of submarine melting in the case of lake-calving glaciers. Floating-tongue ice losses were evaluated in terms of overall mass balance and contribution to sea-level rise. The post-Little Ice Age collapse of Yakutat Icefield was driven in part by tidewater calving retreats of adjacent glaciers, the lake-calving retreat of Yakutat Glacier, a warming climate and by the positive feedback mechanisms through surface lowering.
\end{abstract}

\section{INTRODUCTION}

\section{Lake-calving glaciers}

The dynamics of tidewater glaciers have received much attention because the large and rapid mass losses often associated with instability of these glaciers is important for sea-level rise (Meier and others, 2007; Pfeffer and others, 2008). However, much less is known about the contributions to sea-level rise from lake-calving (lacustrine) glacier systems despite the growing number of such systems worldwide. Proglacial lakes commonly form at the termini of glaciers as they retreat through overdeepened channels formed by glacier erosion (Warren and Aniya, 1999). These proglacial lakes can then modify glacier behavior through flotation, increased calving and ice flow, and accelerating terminus retreat (e.g. Funk and Röthlisberger, 1989; Warren and Kirkbride, 2003). The shift in terminus dynamics can play a significant role in lacustrine situations at many spatial scales ranging from small alpine glaciers terminating in cirque basins to valley lakes (Boyce and others, 2007; Dykes and others, 2010), to large lake-calving glaciers such as those in Patagonia (Warren and others, 1995; Warren and Aniya, 1999; Naruse and Skvarca, 2000; Warren and others, 2001), to lakes surrounding the Laurentide ice sheet at the end of the Last Glacial Maximum (Cutler and others, 2001). The current melting and retreat of the Greenland ice sheet is likely to increase the number of ice-marginal lakes there, introducing another component of dynamic and accelerated ice loss. Data on calving flux, ice flow and surface mass balance on lake-calving glaciers are, with few exceptions, virtually nonexistent. Thus it is difficult to assess the relative importance of overall ice loss for lake-terminating glaciers and its relevance to global sea-level rise.
Most glaciers along the Gulf of Alaska have been retreating and thinning since achieving their Little Ice Age (LIA) maximums sometime between AD 1750 and 1900, in some cases quite rapidly. This ice loss has contributed significantly to rising sea level and has been linked to climate warming (Arendt and others, 2002). In fact, a majority of temperate mountain glaciers worldwide are thinning and retreating (Solomon and others, 2007). Although their volume is a small percentage of the world's total land ice mass, they are important contributors to global sea-level rise (Meier and others, 2007; Pfeffer and others, 2008; Radić and Hock, 2011). During the period 1962-2006, Alaskan glaciers were responsible for $7.5 \%$ of the recent estimate of sea-level rise (Berthier and others, 2010). The relationship between glacier thinning/retreat and climate is complicated for glaciers that lose mass through calving (Post and others, 2011). Calving is an important ice-loss mechanism, and can result in much larger volume loss than would be possible through surface ablation alone (Van der Veen, 2002). However, studies have shown that calving rates for laketerminating glaciers tend to be much lower (by up to an order of magnitude) than for their tidewater calving cousins for equivalent water depths (for reviews see Van der Veen, 2002; Benn and others, 2007). Furthermore, near-terminus surface slopes of tidewater glaciers are typically steeper than lakecalving termini, resulting in near-terminus ice speeds differing by an order of magnitude, with retreating tidewater glaciers often flowing at speeds of $5-10 \mathrm{~km} \mathrm{a}^{-1}$ compared to 100-1000 $\mathrm{m} \mathrm{a}^{-1}$ for lake-terminating glaciers.

The reasons for the major differences in terminus dynamics between tidewater and lake-calving glaciers remain unexplained. We can distinguish at least three environmental 

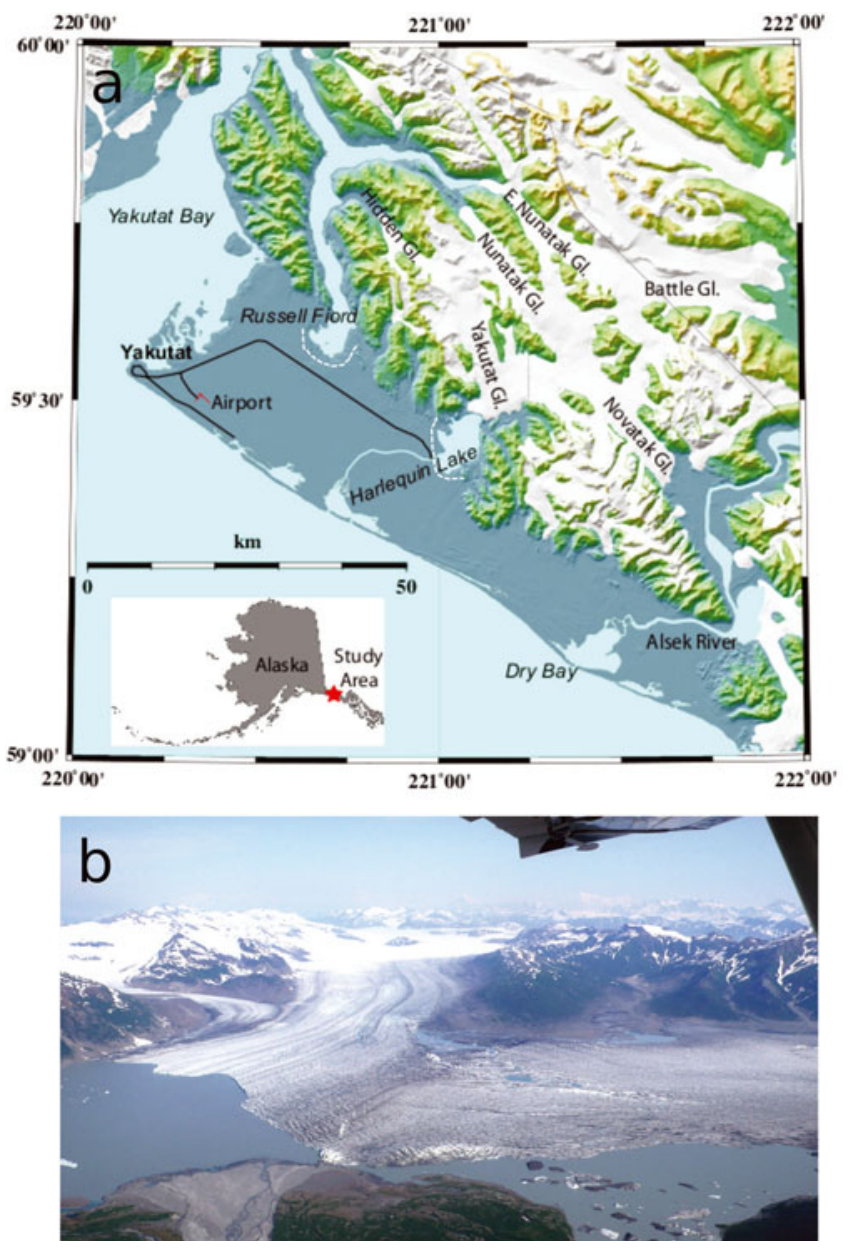

Fig. 1. (a) Yakutat Icefield with Yakutat, Hidden, West Nunatak, East Nunatak, Battle and Novatak Glaciers. The LIA extents at the southern tip of Russell Fjord and for Yakutat Glacier are shown in dashed white. (b) Terminus area of Yakutat Glacier, 17 July 2009.

factors that may be partially responsible for these differences: (1) tidal forcing only affects tidewater glaciers, (2) a strong density contrast exists between fresh water and sea water for tidal systems, and (3) glacial lakes tend to be colder and less stratified as lakes are closed basins with no heat exchange with the ocean. These differences result in very different circulation patterns, which can drive heat transport and influence calving rates. Despite these differences, calving losses can play a significant role in glacier mass balance for lake-terminating glaciers. For example, calving losses at Glaciar Perito Moreno, Patagonia, account for $40 \%$ of total ice loss there (Stuefer and others, 2007). At the other extreme, calving losses at Mendenhall Glacier, a small valley glacier near Juneau, Alaska, USA, account for only $4 \%$ of the total ice loss (Motyka and others, 2003a; Boyce and others, 2007). As with tidewater glaciers, retreat of lake-terminating glaciers into deeper water can result in positive feedback: as the terminus approaches and exceeds flotation, ice flow may accelerate, causing drawdown of up-glacier ice and extensional thinning. The terminus eventually breaks up into large tabular blocks as ice weakens and fractures. In southeast Alaska, Larsen and others (2007) found that calving glaciers accounted for over two-thirds of the ice loss and found that lake-calving glaciers thinned faster per unit area than tidewater glaciers. Yakutat Glacier (Fig. 1a) was identified as having one of the highest rates of ice loss during the period 1948-2000 (Larsen and others, 2007).
In this paper, we investigate the continued ice loss of the Yakutat Ice Field (YIF), focusing on the period 2000-10. We use three digital elevation models (DEMs), one from NASA Shuttle Radar Topography Mission (SRTM) and two from Système Pour l'Observation de la Terre (SPOT) imagery. Lidar profiles, flown nearly concurrently with the SPOT image acquisitions, provide a check on SPOT DEM reliability. We partition mass loss due to calving vs surface mass balance in order to determine their relative contributions and to assess the role of glacier dynamics in ice loss. The YIF consists of both land-terminating and lake-calving glaciers, thus allowing comparison of ice losses from systems experiencing different terminus dynamics, but which are affected by the same climate.

\section{Study area}

Yakutat Glacier (337 km²; Raup and others, 2007) lies on the western (maritime) side of the northern Brabazon Range in southeast Alaska, $50 \mathrm{~km}$ east of the town of Yakutat (Fig. 1a), where annual precipitation rates exceed $3800 \mathrm{~mm} \mathrm{a}^{-1}$ (http:// paya.arh.noaa.gov/clim.php). The glacier is the main outlet of the $810 \mathrm{~km}^{2}$ YIF (Raupand others, 2007) and consists of two main tributaries, each $\sim 25 \mathrm{~km}$ long, that flow from ice divides at $700 \mathrm{~m}$ elevation. Until 2010, the tributaries joined in Harlequin Lake (elevation $28 \mathrm{~m}$ ) and terminated in a $5 \mathrm{~km}$ wide lake-calving front (Fig. 1b). The 1973-82 equilibriumline altitude (ELA) at nearby Variegated Glacier averaged $\sim 1000 \mathrm{~m}$, with annual variations of up to $300 \mathrm{~m}$ (Eisen and others, 2001). Thus, YIF's highest surface elevation is at or below the current ELA for this region, thereby ensuring continuing glacier thinning.

Yakutat Glacier began retreating after reaching its LIA maximum, which likely occurred during the mid-18th century (Barclay and others, 2001). By 1903, Harlequin Lake had begun to form as the glacier retreated into an overdeepened basin (Fig. 2; International Boundary Commission (IBC) maps, IBC, 1952). Harlequin Lake continued to expand as the glacier retreated another $13 \mathrm{~km}$ during the 20th century. The lake area was $69 \mathrm{~km}^{2}$ in 2010. Yakutat Glacier thinned at an average rate of $2.7 \pm 0.3 \mathrm{~m}$ w.e. $\mathrm{a}^{-1}$ between 1948 and 2000 (Larsen and others, 2007), with similar rates observed at other YIF glaciers. This rapid ice loss has resulted in solid-Earth uplift rates from glacier rebound which are currently among the highest in the world $\left(\sim 32 \mathrm{~mm} \mathrm{a}^{-1}\right.$; Larsen and others, 2005). IBC maps indicate that East and West Nunatak Glaciers were still connected at the terminus and calved into Nunatak Fjord (Fig. 2). These glaciers are now land-terminating and have been for at least half a century.

\section{METHODS \\ Digital elevation models}

We compared three DEMs from 2000, 2007 and 2010 to evaluate glacier thinning. The first DEM was derived from Cband data of the SRTM collected in February 2000, with a spatial resolution of 1 arcsec or $\sim 30 \mathrm{~m}$ (Rodríguez and others, 2006). Larsen and others (2007) compared the SRTM DEM to lidar profiles flown over southeast Alaska to obtain an estimate of SRTM vertical uncertainties. Their analysis resulted in an elevation-dependent correction to address seasonal differences and radar penetration and also provided an estimated gridpoint uncertainty of $5 \mathrm{~m}$. We have 


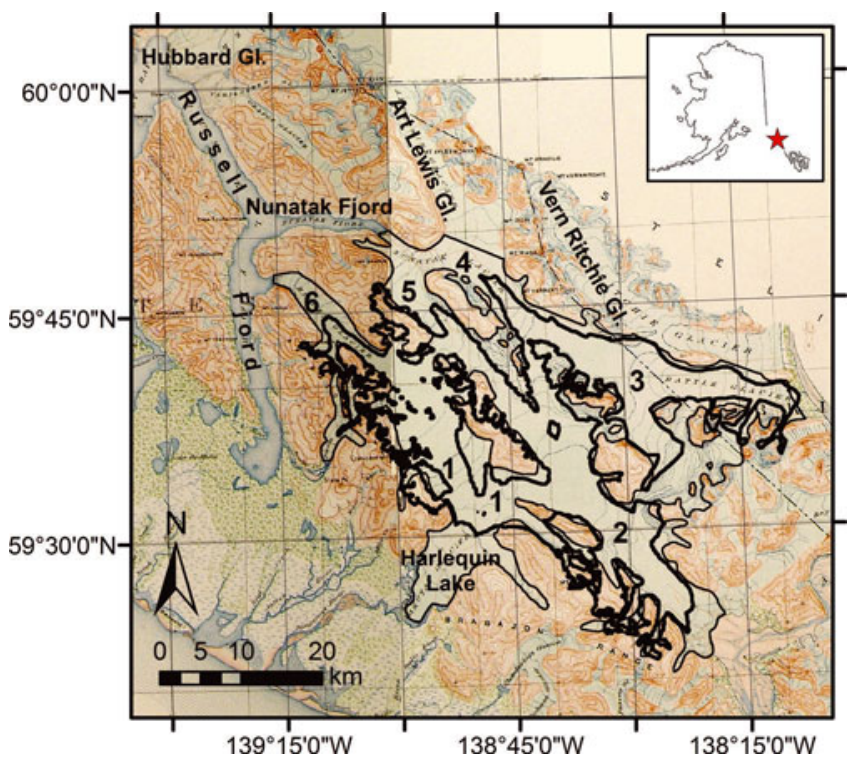

Fig. 2. IBC map from 1903 (IBC,1952) showing the YIF with (1) Yakutat Glacier, (2) Novatak Glacier, (3) Battle Glacier, (4) East Nunatak Glacier, (5) West Nunatak Glacier and (6) Hidden Glacier. Glacier outlines in bold black depict the glacier extent in 2005, based on the GLIMS database. Proglacial Harlequin Lake began forming in 1903, when Nunatak Glacier was still a tidewater glacier (1903 outline in fine black).

adopted these results for our comparisons of the YIF SRTM DEM to other DEMs.

The other two DEMs have a spatial resolution of $40 \mathrm{~m}$ and were generated from SPOT 5 imagery, acquired on 3 September 2007 and 20 September 2010 (Korona and others, 2009). We masked poorly resolved areas using boundaries supplied with the DEMs. In order to evaluate and correct any elevation errors we compared SPOT DEMs over the YIF to light-aircraft laser altimetry acquired under Operation IceBridge (Larsen, 2010) and earlier University of Alaska Fairbanks glacier altimetry. Lidar data were obtained on 26 August 2007 in profile mode (vertical precision $\pm 0.3 \mathrm{~m}$ and point-spacing $1.2 \mathrm{~m}$ ) and on 29 August 2010 in scanning mode (vertical precision $\pm 0.3 \mathrm{~m}$ and point-spacing $\left.1 \mathrm{~m}^{-2}\right), 8$ and 22 days before SPOT acquisitions. We corrected for melt between the lidar and SPOT acquisition dates. Measurements of summer mass balance for Yakutat Glacier from 2009 and 2010 showed a linear relationship between elevation and melt. A linear function based on these data was then combined with the mean melt recorded by ablation meters (Bøggild and others, 2004) on the floating tongue $\left(0.08 \mathrm{~m} \mathrm{~d}^{-1}\right)$ to obtain a melting correction for the dates of the 2007 lidar and SPOT DEM. We estimate the associated uncertainty at $\pm 0.1 \mathrm{~m}$. The same method was used to correct for melting between the 2010 SPOT DEM and lidar data, except only August 2010 ablation-meter $\left(\sim-0.08 \mathrm{~m} \mathrm{~d}^{-1}\right)$ and summer mass-balance data were used.

Elevation differences between lidar data and the SPOT DEMs were approximately normally distributed, with some outliers at either end. Most of these occur in crevassed terminus regions. The others occur over steep bedrock nunataks near the ice divide and probably reflect the difference in grid resolution between the two datasets. We therefore filtered out clear outliers with elevation differences

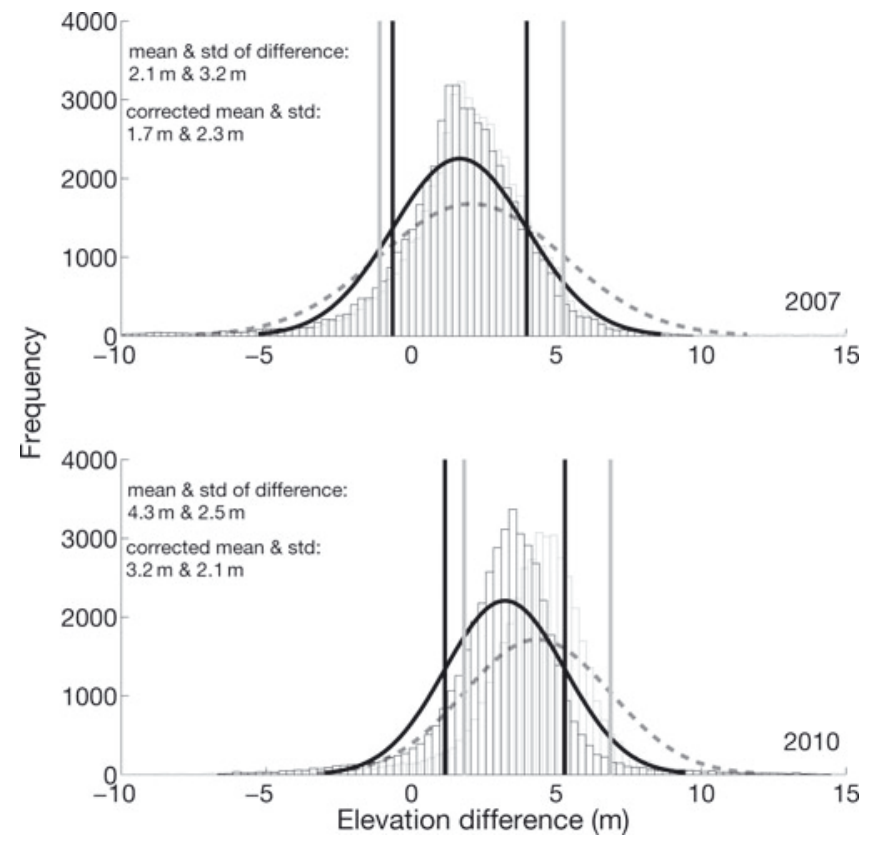

Fig. 3. Distribution of laser altimetry minus SPOT elevation differences flown over the YIF. The raw data (gray) were corrected by excluding elevation differences exceeding $\pm 10 \mathrm{~m}$ and by applying an elevation-dependent melt correction function (black). The black curve is a normal fit over the corrected distribution, and the dashed gray curve represents a normal fit through raw data. Vertical bars illustrate the area within the standard deviation.

exceeding $\pm 10 \mathrm{~m}$, and then corrected for melt as outlined above. The elevation differences for both uncorrected and corrected data are shown in Figure 3. The corrected differences were then used to define a linear elevationdependent vertical bias correction for both years, which was applied to the original SPOT DEMs before differencing.

\section{Digital elevation model differencing}

We differenced the DEMs using Quick Terrain Modeler (version 7.1.2) to produce an elevation-change $(\Delta Z)$ DEM with grid spacing of $40 \mathrm{~m}$. The glacier mask for the YIF was created using data from GLIMS (Global Land Ice Measurements from Space; Raup and others, 2007), Landsat imagery and USGS (US Geological Survey) Topo maps.

Elevation changes at the glacier margins along steep valley walls can be poorly resolved due to grid spacing and mismatched gridpoints. Thus, the mask was downscaled by two pixels (pixel size $40 \mathrm{~m} \times 40 \mathrm{~m}$ ) along the edges to minimize such errors. Outliers in the $\Delta Z$ distribution (Fig. 3) are from snow-covered areas, where the uncertainty of the DEM is large, and from glacier margins. The latter are most likely an artifact of edge proximity that was not caught by downsizing the outline mask. Thus, pixels with $\Delta Z$ greater than $+35 \mathrm{~m}(0.04 \%$ of the YIF $)$ and less than $-105 \mathrm{~m}$ $(<0.01 \%)$ for $2000-07$, and greater than $+15 \mathrm{~m}(0.15 \%)$ and less than $-45 \mathrm{~m}(0.01 \%)$ for $2007-10$, were eliminated.

We neglected uplift and assumed no changes in elevation of the glacier bed, such as may be caused by erosion and sediment deposition. The uplift rate in the YIF area, $32 \mathrm{~mm} \mathrm{a}^{-1}$ (Larsen and others, 2005), although large, is negligible compared to the mean $\Delta H / \Delta t$ of the ice field. With the exception of the floating terminus of the YIF, $\Delta Z$ derived from the differenced DEM can be used directly to calculate ice volume change and thinning rates, $\Delta H / \Delta t$. 

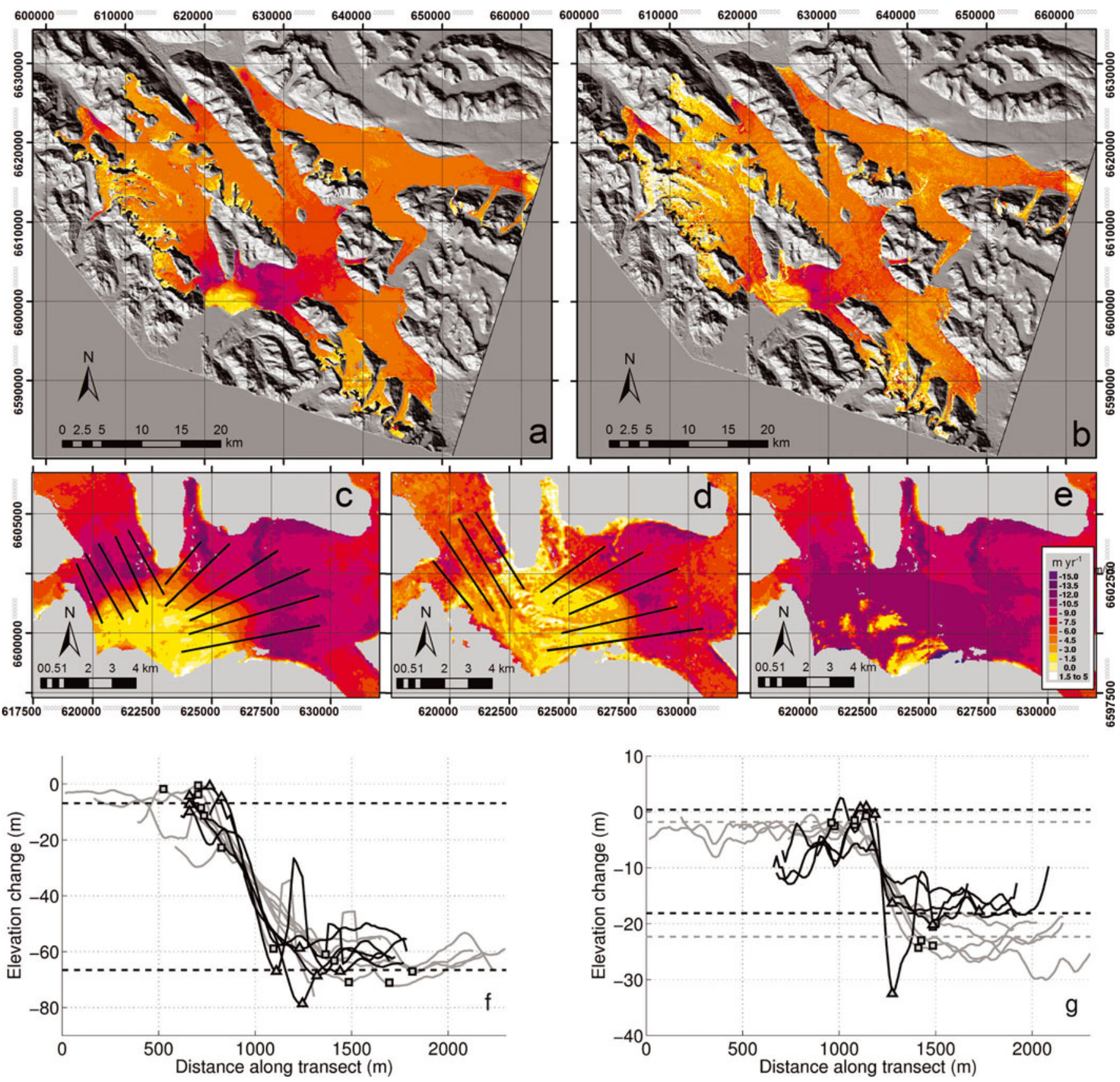

Fig. 4. $(\mathrm{a}, \mathrm{b})$ Glacier surface elevation change rates $\left(\Delta Z / \Delta t ; \mathrm{m} \mathrm{a}^{-1}\right)$ of the YIF before correcting for the floating tongue: (a) 2000-07 and (b) 2007-10. (c, d) Elevation changes $\Delta Z$ and locations of transects for (c) 2000-07 and (d) 2007-10. (e) The corrected ice thickness change $\Delta H$ (2000-07). (f, g) The transects of the terminus area ((c) and (d) for location) used to define a transition zone between the grounded ice (right side of each panel defined by large $\Delta Z$ ) and the floating tongue (left side). Black transects were derived from the western part of the terminus, and gray from the eastern part. Points mark the change from one zone to another (squares for the western, triangles for the eastern part). Dashed lines represent the mean $\Delta Z$ for the floating (upper) line and grounding (lower) line, based on the hand-picked points.

However, a different strategy must be employed when assessing ice loss for the floating terminus of Yakutat Glacier. We identify four zones: (1) grounded ice, (2) free-floating ice, (3) a transition zone between the two, and (4) the area of terminus that retreated between dates of the DEMs (see Appendix). Figure 4c and d show the locations of a series of transects through the differenced DEMs. The change in $\Delta Z$ along these transects helps define these different zones (Fig. $4 \mathrm{f}$ and g). For grounded ice, $\Delta Z$ is a direct measure of ice loss. For the floating tongue, buoyancy must be taken into account. Here we assume hydrostatic equilibrium with an ice density of $900 \mathrm{~kg} \mathrm{~m}^{-3}$ and freshwater density of
$1000 \mathrm{~kg} \mathrm{~m}^{-3}$ so that ice thinning is given by $\Delta H=10 \Delta Z$. Ice in the transition zone was originally grounded but is now floating. To assess $\Delta H$, we apply a linear trend as a function of distance to evaluate $\Delta H$ between the grounding line and the floating tongue.

The fourth zone, the area of the terminus retreat, was identified using SRTM and SPOT images. The area of retreat was assumed to have been in hydrostatic equilibrium, so surface elevations derived from the DEMs were multiplied by 10 to determine total ice loss. Some regions near lateral margins are likely partially grounded, so corrections were made for these regions. All four zones changed over time 
Table 1. Area and volume changes for glaciers comprising the YIF: lake-calving Yakutat and Battle Glaciers and the other, land-terminating, glaciers. The three different lines for Yakutat Glacier reflect uncorrected values, values corrected for the floating tongue in terms of ice loss $(\mathrm{MB})$ and values corrected for mass loss of the glacier-lake system (SLR). $\Delta V$ is the volume change, $\sigma_{\Delta A}$ is the area elevation uncertainty, $\sigma_{V}$ is the volume change uncertainty ( 1 for a correlated uncertainty and 2 for an assumed correlation length of $150 \mathrm{~m}$ ) and $\overline{\mathrm{MB}}$ is the mean mass balance. The accumulation-area ratio (AAR) was derived from the 2007 SPOT DEM

\begin{tabular}{|c|c|c|c|c|c|c|c|}
\hline \multirow[t]{2}{*}{ 2000-07 } & Area & $\Delta V$ & $\sigma_{\Delta A}$ & $\sigma_{v} 1$ & $\sigma_{V^{2}}$ & $\overline{\mathrm{MB}}$ & $\sigma_{\mathrm{MB}}$ \\
\hline & $\mathrm{km}^{2}$ & $\mathrm{~km}^{3}$ & $\mathrm{~m}$ & $\mathrm{~km}^{3}$ & $\mathrm{~km}^{3}$ & m w.e. $a^{-1}$ & \\
\hline Yakutat & 337.12 & -11.16 & 0.48 & 0.16 & 1.85 & -4.25 & 0.06 \\
\hline Yakutat (MB) & 337.12 & -12.48 & 0.48 & 0.16 & 1.85 & -4.76 & 0.06 \\
\hline Yakutat (SLR) & 337.12 & -11.07 & 0.48 & 0.16 & 1.85 & -4.22 & 0.06 \\
\hline East Nunatak & 66.43 & -1.82 & 1.08 & 0.07 & 0.37 & -3.52 & 0.14 \\
\hline West Nunatak & 81.85 & -1.86 & 0.97 & 0.08 & 0.45 & -2.93 & 0.13 \\
\hline Novatak & 116.08 & -2.63 & 0.82 & 0.10 & 0.64 & -2.91 & 0.11 \\
\hline Hidden & 58.96 & -1.27 & 1.15 & 0.07 & 0.32 & -2.77 & 0.15 \\
\hline Battle & 149.06 & -3.79 & 0.72 & 0.11 & 0.82 & -3.27 & 0.09 \\
\hline Total (YIF) & 809.51 & -22.53 & 0.31 & 0.25 & 4.45 & -3.58 & 0.04 \\
\hline YIF corrected (MB) & 809.51 & -23.85 & 0.31 & 0.25 & 4.45 & -3.79 & 0.04 \\
\hline YIF corrected (SLR) & 809.51 & -22.44 & 0.31 & 0.25 & 4.45 & -3.56 & 0.04 \\
\hline & $\mathrm{km}^{2}$ & $\mathrm{~km}^{3}$ & $\mathrm{~m}$ & $\mathrm{~km}^{3}$ & m w.e. $a^{-1}$ & & \\
\hline Yakutat & 337.12 & -3.31 & 0.36 & 0.12 & -2.95 & 0.05 & 0.03 \\
\hline Yakutat (MB) & 337.12 & -4.11 & 0.36 & 0.13 & -3.66 & 0.05 & 0.03 \\
\hline Yakutat (SLR) & 337.12 & -3.22 & 0.36 & 0.12 & -2.87 & 0.05 & 0.03 \\
\hline East Nunatak & 66.43 & -0.71 & 0.81 & 0.05 & -3.24 & 0.10 & 0.02 \\
\hline West Nunatak & 81.85 & -0.62 & 0.73 & 0.06 & -2.28 & 0.09 & 0.07 \\
\hline Novatak & 116.08 & -0.85 & 0.61 & 0.07 & -2.26 & 0.08 & 0.06 \\
\hline Hidden & 58.96 & -0.31 & 0.86 & 0.05 & -1.62 & 0.11 & 0.13 \\
\hline Battle & 149.06 & -1.32 & 0.54 & 0.08 & -2.66 & 0.07 & 0.02 \\
\hline Total (YIF) & 809.51 & -7.12 & 0.23 & 0.19 & -2.64 & 0.03 & 0.04 \\
\hline YIF corrected (MB) & 809.51 & -7.92 & 0.23 & 0.19 & -2.94 & 0.03 & 0.04 \\
\hline YIF corrected (SLR) & 809.51 & -7.03 & 0.23 & 0.19 & -2.61 & 0.03 & 0.04 \\
\hline
\end{tabular}

and were determined separately for 2000-07 and 2007-10. Details of the treatment of the four zones are provided in the Appendix.

Our geodetic DEM differencing approach assesses the total mass loss of the YIF, including surface mass balance and mass loss due to calving. Retreat of a floating tongue does not lead to mass changes in the local glacier-lake system, and in the transition zone only a portion of the thinning ice leaves the lake-glacier system. To allow comparisons to other results, we evaluate ice loss in two different ways. For example, sensors such as GRACE (Gravity Recovery and Climate Experiment) only measure total mass change, which directly translates to eustatic sea-level rise. However, mass-balance studies need to account for all ice that is lost, regardless of whether some of the meltwater remains in the lake. In neither case do the values follow directly from measured $\Delta Z$.

We now address the question of estimating the uncertainty of determining volume change and geodetic mass balance. The total change in ice volume is determined by differencing the DEMs and summing gridpoints either over the area of the YIF or over individual glaciers. The volume change can in turn be converted to mass (expressed as water equivalent volume, w.e.) if the ice density is known, and further converted to an area-wide specific mass balance by dividing by the area.

When estimating the uncertainty of such calculations, two extreme approaches have commonly been applied
(Rolstad and others, 2009). One approach uses the uncertainty of point measurements (i.e. the standard deviation of the elevation error) to represent the integrated uncertainty: the point uncertainty is essentially treated as being totally correlated across the area of integration (Cox and March, 2004; Larsen and others, 2007). At the other extreme, uncertainties of point measurements are treated as random uncorrelated errors (Rignot and others, 2003). In this case, uncorrelated integrated errors will be a factor $n^{1 / 2}$ smaller than correlated errors, where $n$ is the number of gridpoints over which the spatial integration is carried out. Following methodology developed by Rolstad and others (2009) and outlined in Motyka and others (2010), we chose an intermediate method of estimating uncertainties, that of using variograms of the differenced DEMs over adjacent land areas to determine an area of correlation, $A_{C}$, which is then taken as a measure of error correlation between the two DEMs over the ice.

For comparison of the SPOT DEMs, we found $A_{\mathrm{C}}=0.07 \mathrm{~km}^{2}$, which is considerably smaller then the area, $A$, both for the YIF $\left(810 \mathrm{~km}^{2}\right)$ and for the individual glaciers. Table 1 provides the variance of the mean of the area, $\sigma_{\Delta A^{\prime}}$ and $\sigma_{V}$, the uncertainty in volume change, calculated using relationships discussed in Motyka and others (2010).

Assessing similar uncertainties for the SRTM vs 2007 SPOT DEMs is more problematic as we are unable to derive suitable variograms due to the seasonal difference. In the most pessimistic case we assume that the elevation 
Table 2. Volume change for the different zones of Yakutat Glacier resulting from DEM differencing. MB denotes mass-balance calculations, and SLR the contribution to sea-level rise

\begin{tabular}{|c|c|c|c|c|}
\hline & \multicolumn{2}{|c|}{ Surface area } & \multicolumn{2}{|c|}{ Volume change } \\
\hline & $2000-07$ & $2007-10$ & 2000-07 & $2007-10$ \\
\hline & $\mathrm{km}^{2}$ & $\mathrm{~km}^{2}$ & $\mathrm{~km}^{3}$ & $\mathrm{~km}^{3}$ \\
\hline Differenced DEM & 337.12 & 329.37 & -11.16 & -3.31 \\
\hline Adjusted differenced DEM (MB) & 338.90 & 328.23 & -12.48 & -4.11 \\
\hline Grounded & 311.12 & 295.24 & -10.05 & -3.04 \\
\hline Transition & 16.35 & 12.11 & -1.14 & -0.24 \\
\hline Transition (GRACE) & 16.35 & 12.11 & -0.85 & -0.17 \\
\hline Floating & 9.38 & 17.21 & -0.43 & -0.32 \\
\hline Retreated & 2.05 & 3.67 & -0.41 & -0.51 \\
\hline
\end{tabular}

difference uncertainty of $5.5 \mathrm{~m}$ is correlated across the entire area. The corresponding uncertainty in volume change for YIF is then $4.5 \mathrm{~km}^{3}$ compared to $0.25 \mathrm{~km}^{3}$ for an assumed correlation length of $150 \mathrm{~m}$ (Table 1 ).

Additional uncertainties accrue from our treatment of the floating tongue. These uncertainties are discussed in the Appendix: they increase the uncertainty in volume change of Yakutat Glacier by $0.01 \mathrm{~km}^{3}$ but do not influence the remainder of the YIF. Uncertainties due to changes in ice and firn density are considered negligible here, since almost all of the YIF glacier area is below the snowline.

\section{Calving flux}

Calving flux $Q_{C}\left(\mathrm{~m}^{3} \mathrm{a}^{-1}\right)$ is the difference between ice flux arriving at the calving front and the volume change at the terminus (advance/retreat):

$$
Q_{\mathrm{c}}=Q_{\text {in }}-\frac{\mathrm{d} V}{\mathrm{~d} t}
$$

where $Q_{\text {in }}$ is the ice flux and rate of retreat is $\frac{d V}{d t}\left(\mathrm{O}^{\prime}\right.$ Neel and others, 2003).

\section{Terminus retreat}

We used Landsat 7 satellite imagery (http://glovis.usgs.gov/) panchromatic band (spatial resolution $15 \mathrm{~m}$ ) taken on 2 September 2000 and the georeferenced SPOT images for 2007 and 2010 to determine the amount of retreat of Yakutat Glacier. To obtain volume change, we subtracted the lakelevel elevation from the retreated part of the 2000 DEM for the first time period and 2007 DEM for the second period. The resulting elevation of the ice surface above lake level was multiplied by 10 to obtain the ice thickness assuming hydrostatic equilibrium.

\section{Ice flux}

The depth-averaged velocity on the floating tongue is essentially equal to the surface velocity, due to the lack of basal drag. However, the velocity is not uniform along the terminus. We obtained a surface velocity field over the terminus area by feature tracking (Scambos and others, 1992) using Landsat 7 imagery (2 September 2000 and 21 September 2001, 16 August 2002 and 10 August 2003, 15 October 2004 and 2 October 2005, 8 October 2007 and 24 September 2008) and orthomosaics based on vertical aerial photography flown on 17 July 2009 and 25 August 2010. These velocities were binned into $150 \mathrm{~m}$ sections across the $5 \mathrm{~km}$ wide terminus for Landsat images and $80 \mathrm{~m}$ sections for the orthomosaics. The velocities varied from year to year due to grounding effects of the floating terminus advancing onto the south shore of Harlequin Lake. We used a mean velocity, $v_{\mathrm{d}}$, over $2 \mathrm{~km}$ length of the floating tongue to represent each bin of width $w_{\mathrm{d}}$. The ice flux was then determined from

$$
Q_{\text {in }}=\sum v_{\mathrm{i}} \cdot w_{\mathrm{i}} \cdot h_{\mathrm{i}}
$$

where $h_{\mathrm{d}}$ is the mean ice thickness of each bin, determined from a cross section (flux gate) of the SRTM DEM and a DEM generated from 2009 orthophotos (unpublished data by the authors; DEM covers terminus area of Yakutat Glacier). We determined the range of scatter in each bin to assess a mean uncertainty of $5.6 \mathrm{~m} \mathrm{a}^{-1}$ for the first period and $12.6 \mathrm{~m} \mathrm{a}^{-1}$ for the second.

\section{Long-term retreat}

We estimated long-term thinning of the YIF by comparing center-line contour crossing elevations from 1903 IBC maps (cf. Fig. 2) to the 2010 SPOT DEM. Based on comparisons of land features to USGS Topo maps, the uncertainty for the IBC map elevations is $\sim 40 \mathrm{~m}$ (half contour interval). For reconstruction of the terminus retreat during the 20th century, we used terminus outlines derived from IBC maps (1903), an air photo by B. Washburn (1934), a US National Elevation Dataset (NED) DEM (1948), air photos by A. Post (1960-78) and Landsat imagery (1973-2010). The outlines were digitized and georeferenced by hand using the software ENVI (version 4.4). We calculated retreat by determining the area defined by a $1400 \mathrm{~m}$ wide bar intersecting with terminus positions to ensure a representative retreat rate.

\section{RESULTS}

\section{DEM differencing}

DEM differencing revealed that the entire YIF experienced strong thinning for both periods. Thinning rates ranged from 3.0 to $2.0 \mathrm{~m} \mathrm{a}^{-1}$ at the ice divides and increased downglacier to $\sim 10.5 \mathrm{~m} \mathrm{a}^{-1}$ near the terminus of Yakutat Glacier (Fig. 4a and b). The total ice volume loss and mean mass balance between 2000-07 and 2007-10 for the YIF and for the individual glaciers comprising the YIF are summarized in Table 1, together with error estimates. Table 2 presents results specific to Yakutat Glacier. We report results from 
DEM differencing with and without corrections for the floating terminus. Ice losses in the region of the floating tongue were evaluated as described in the Methods section and Appendix: one for mass-balance calculations and the other for sea-level rise comparison (Table 2). Figure $4 \mathrm{e}$ shows the differenced DEM (2000-07) of the terminus area of Yakutat Glacier with its floating tongue and after corrections have been applied.

Lake-calving Yakutat Glacier experienced the highest area-averaged mass balance of the YIF: $-4.76 \pm 0.06$ and $-3.66 \pm 0.05 \mathrm{~m}$ w.e. $\mathrm{a}^{-1}$ for $2000-07$ and 2007-10 respectively (Fig. 4a and b; Table 1). In contrast, land-terminating glaciers experienced typically $\sim 1$ m w.e. $\mathrm{a}^{-1}$ less mass loss than Yakutat Glacier.

\section{Calving flux}

\section{Terminus retreat}

The west branch of Yakutat Glacier lost $2.1 \mathrm{~km}^{2}$ between 2000 and 2007: with a mean calving front width of $4.2 \mathrm{~km}$ (4.1 km in 2000 and $4.2 \mathrm{~km}$ in 2007), the mean linear retreat rate was $49 \mathrm{~m} \mathrm{a}^{-1}$, and with a total ice volume loss of $0.41 \pm$ $0.16 \mathrm{~km}^{3}$ the rate of retreat, $\frac{\mathrm{d} V}{\mathrm{~d} t}$, was $0.06 \pm 0.02 \mathrm{~km}^{3} \mathrm{a}^{-1}$ for 2000-07.

Several large tabular icebergs calved from the floating tongue between 2007 and 2010, resulting in a net retreat of $3.67 \mathrm{~km}^{2}$ and a $5.6 \mathrm{~km}$ wide calving front in 2010 . The calving was episodic, but the mean linear retreat rate was $273 \mathrm{~m} \mathrm{a}^{-1}$. The total ice volume lost by retreat between 2007 and 2010 was $0.51 \pm 0.04 \mathrm{~km}^{3}$, resulting in a rate of retreat, $\frac{\mathrm{d} V}{\mathrm{~d} t}$, of $0.17 \pm 0.01 \mathrm{~km}^{3} \mathrm{a}^{-1}$ for 2007-10.

\section{Ice flux}

The velocity field in the terminus region determined from feature tracking is shown in Figure 5a. The binned velocities were averaged for the two time periods (Fig. 5b and c). Ice velocities were highest on the west branch, where the maxima for each time period varied between 139.2 \pm 5.6 and $150.6 \pm 12.6 \mathrm{~m} \mathrm{a}^{-1}$ and decreased towards the confluence between the east and west branches. Some velocities varied between years by as much as $88.9 \mathrm{ma}^{-1}$ between 2007/08 and 2009/10. We attribute this change to a local advance onto land at the south end (Fig. 5a). A generally stagnant east branch creates a shear zone at the confluence.

The mean ice thickness $h_{\mathrm{d}}$ for each bin, determined from 2000 and 2009 DEMs, was multiplied by the bin's velocity $v_{\mathrm{d}}$ and width $w_{\mathrm{d}}$. For the first period, $Q_{\text {in }}$ was $0.55 \mathrm{~km}^{3}$ or $0.08 \mathrm{~km}^{3} \mathrm{a}^{-1}$ over a flux-gate length of $4.95 \mathrm{~km}$. For the second period, mean velocities could only be determined for the first $2.8 \mathrm{~km}$ of the flux gate; for the following $2.2 \mathrm{~km}$, velocities from 2007-08 were used, resulting in $Q_{\text {in }}$ of $0.22 \mathrm{~km}^{3}$ or $0.06 \mathrm{~km}^{3} \mathrm{a}^{-1}$. Combining ice flux and terminus retreat following Eqn (1) results in a calving flux of $0.14 \mathrm{~km}^{3} \mathrm{a}^{-1}$ for the first period and $0.23 \mathrm{~km}^{3} \mathrm{a}^{-1}$ for the second period. Comparing calving flux to total volume loss of Yakutat Glacier shows that for the first period (2000-07), only $\sim 7.9 \%$ of the total loss is due to calving, whereas for the second period calving accounts for $\sim 16.8 \%$.

\section{Long-term retreat}

To complement and provide perspective on the recent volume losses we also examined long-term trends in
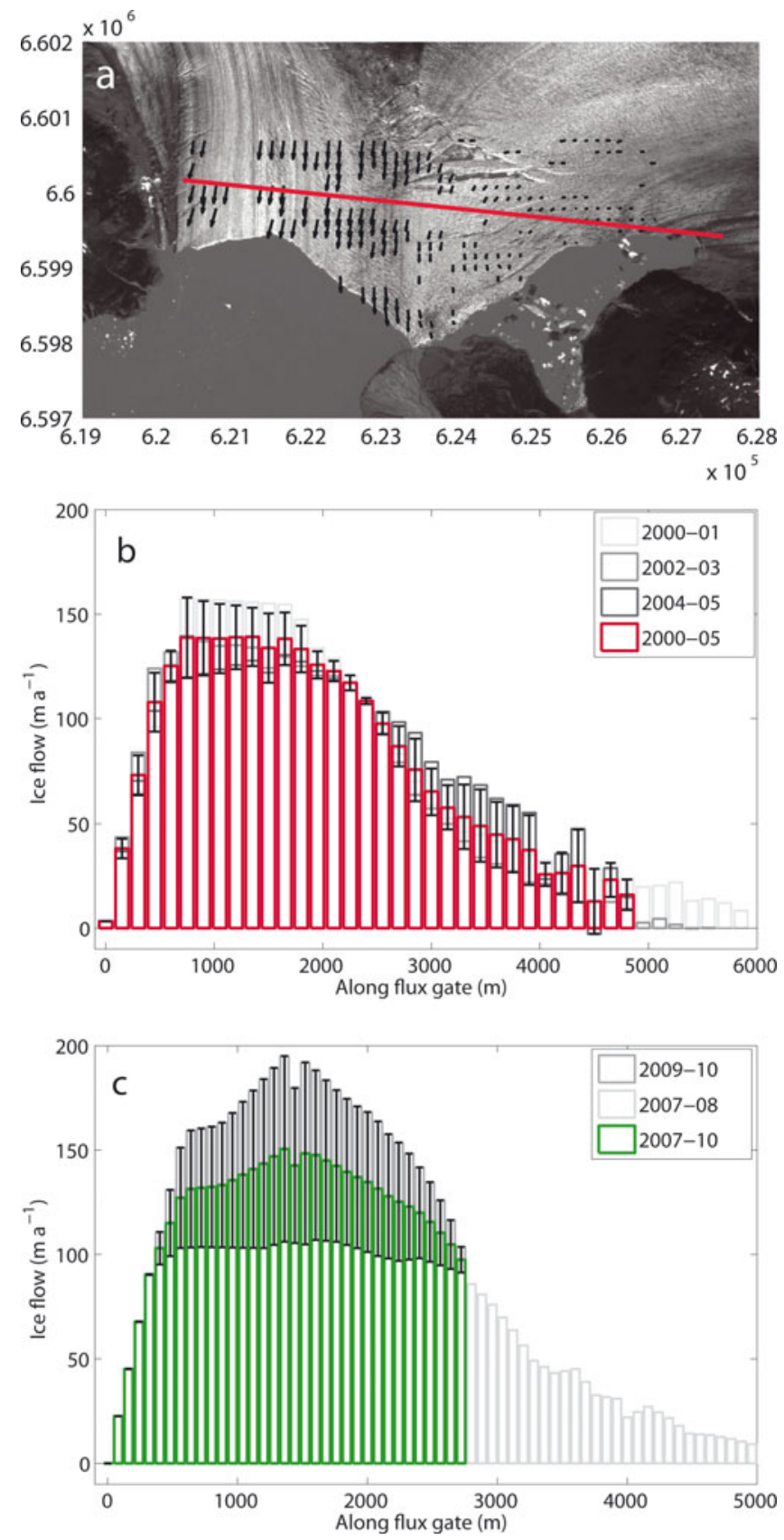

Fig. 5. Feature tracking from Landsat 7 imagery. (a) Spatial distribution and direction of pixel displacements over 349 days (2007-08). The flux gate is indicated by the red line. (b, c) Displacements from four feature-tracking datasets through the flux gate (b) in $150 \mathrm{~m}$ bins for 2000-07 and (c) in $80 \mathrm{~m}$ bins for 2007-10. Error bars (black) are estimated from the mean displacement scatter over all datasets.

thinning and glacier retreat by comparing the center-line elevation of the 1903 IBC maps to the 2010 SPOT DEM (Fig. 6a), and by plotting terminus positions derived from a variety of resources (Fig. 6b and c).

Although glacier contours on the 1903 IBC maps have large uncertainties $( \pm 40 \mathrm{~m})$, they do provide some quantification of total ice loss that has occurred over the last century. For example, the ice surface dropped by $\sim 400 \mathrm{~m}$ during the last century in the region of the 2010 terminus. The maps also suggest that the divides at Yakutat Glacier were about 100 and $200 \mathrm{~m}$ higher on the west and east branches respectively than they are today. 

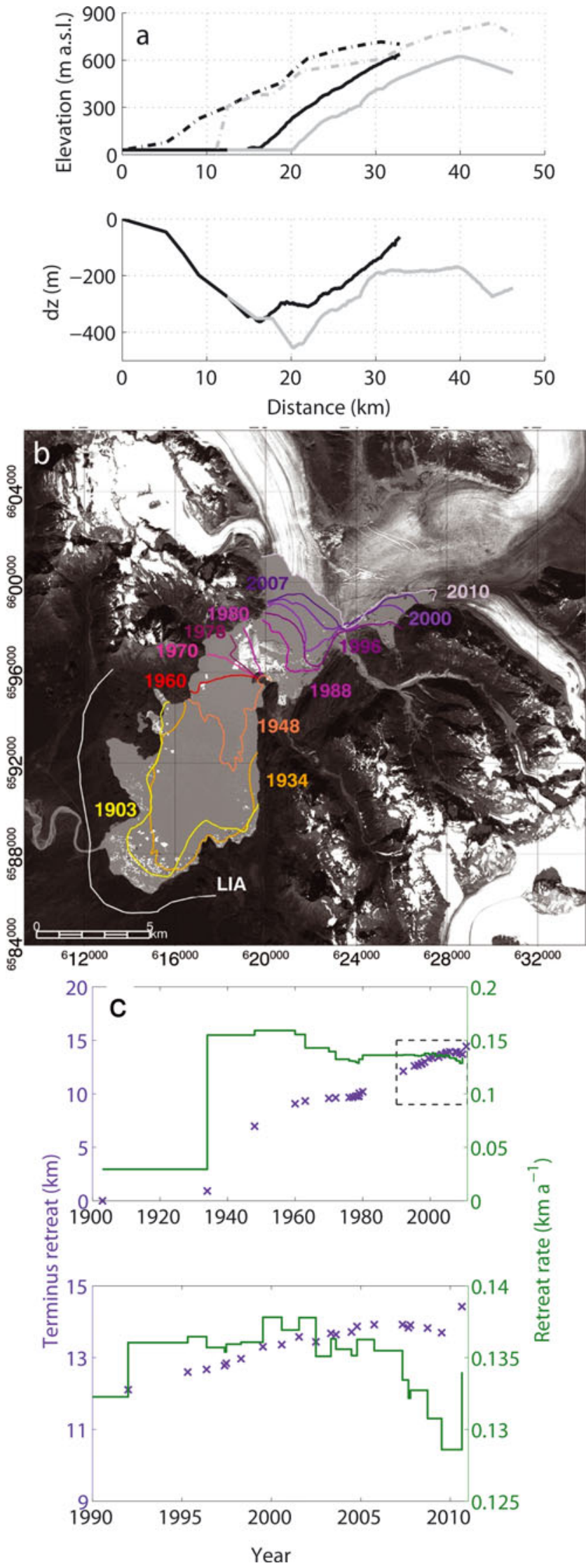

Fig. 6. Evolution of terminus retreat between 1903 and 2010. (a) Elevation of the center line of Yakutat Glacier in 1903 (solid) and 2010 (dashed) for west branch (black) and east branch (gray). Elevation difference (1903-2010) of west branch (black) and east branch (gray) in the lower panel. (b) Selected terminus positions overlaying the 2010 SPOT image. (c) Terminus retreat in relation to the terminus position in 1903 (purple) and retreat rates (green). Detailed data in dashed black box are shown in the lower panel.
The outlines of glaciers comprising the YIF in 1903 (from IBC maps) vs 2005 (GLIMS) illustrate the degree of retreat that has occurred during the last century (Fig. 2). East and West Nunatak were connected as one tidewater glacier in 1903. By 2005 the glacier branches had separated and had retreated 13 and $10.5 \mathrm{~km}$ respectively. Both now terminate on land. Hidden Glacier underwent a retreat of $\sim 7.1 \mathrm{~km}$ and Novatak Glacier experienced $\sim 3.1 \mathrm{~km}$ terminus retreat between 1903 and 2005, whereas Battle Glacier does not appear to have retreated during this period. Yakutat Glacier retreated $\sim 14 \mathrm{~km}$, albeit at highly variable rates.

\section{DISCUSSION}

\section{Recent ice losses and comparison to other studies}

Yakutat Ice Field experienced a total volume loss of $31.77 \pm 0.31 \mathrm{~km}^{3}$ between 2000 and 2010, for an average of $3.18 \pm 0.03 \mathrm{~km}^{3} \mathrm{a}^{-1}$ (Table 1). This includes a correction for the elevation change of the floating tongue, which amounts to $5.9 \%$ of the total for the first period (2000-07) and $11.2 \%$ for the second period (2007-10). Corrections for mass loss calculations of the glacier-lake system are small. For geodetic mass-balance calculations (mw.e. $\mathrm{a}^{-1}$ ) we use mass balance, which includes all ice losses (Table 2). Previous studies did not include this correction. We report our results for mass balance both with and without the floating-tongue contribution. Larsen and others (2007) differenced DEMs from the 1948/62 US National Elevation Dataset (NED) and the 2000 SRTM and obtained an average mass balance of -2.7 m w.e. $\mathrm{a}^{-1}$ over this time-span. Similar results $\left(-2.5 \mathrm{~m}\right.$ w.e. $\left.\mathrm{a}^{-1}\right)$ were reported by Berthier and others (2010) for DEMs from the NED and 2007 SPOT. However, they did not apply the seasonal difference correction as done here from the comparison with 2007 lidar data. Doing so would change their mass-balance results by about -0.03 mw.e. $\mathrm{a}^{-1}$. Arendt and others (2008) used laser altimetry data from 2005 and 2007 and reported a mass balance of $-2.78 \pm 0.66 \mathrm{~m}$ w.e. $\mathrm{a}^{-1}$, a value similar to the other previous studies.

Our results indicate ice loss significantly accelerated during the first decade of the 21st century for both Yakutat Glacier and for the YIF when compared to Larsen and others (2007) and Berthier and others (2010). The reasons for this increase in ice thinning include (1) a positive feedback mechanism, known as the Bodvardsson effect (Bodvardsson, 1955), where thinning lowers the surface elevation and exposes the ice to higher temperatures at lower elevations, causing accelerated ice loss, and (2) climate change. The town of Yakutat has seen a temperature increase of $1.3^{\circ} \mathrm{C}$ and annual precipitation increase of $1528 \mathrm{~mm}$ during the period 1948-2000 (Larsen and others, 2007). During the last decade (2000-10), mean annual temperatures were $0.4^{\circ} \mathrm{C}$ higher, following the general trend of the 20th century. Increased temperature elevates the ELA and decreases the AAR, resulting in increased ice loss. The study by Arendt and others (2008) covers the time period 2005-07, part of our study period. They compared NASA's ATM data (2005) with University of Alaska laser altimetry data (2007) and found an area-averaged mass balance for Yakutat Glacier of $-2.78 \pm 0.66 \mathrm{~m}$ w.e. $\mathrm{a}^{-1}, 34 \%$ lower than what we found for the period 2000-07, which may reflect interannual variations. Additionally, this difference may result from different sources. While laser altimetry data collected along 
a glacier center flowline may not be representative for an entire glacier (Berthier and others, 2010), this is not likely to be an issue in the case of the YIF as the glaciers show uniform surface lowering within elevation bands. However, monthly temperatures from the town of Yakutat reveal a $0.6^{\circ} \mathrm{C}$ lower mean annual temperature during the laser altimetry time period (September 2005 to August 2007) compared to 2000-07. Summer temperatures were comparable, but winter temperatures were lower. Precipitation did not show any trends, but the lower temperatures may have led to higher amounts of solid precipitation. Third, Arendt and others (2008) did not include losses from the floating tongue. Our results (Table 2 ) indicate that this could account for an additional $-0.5 \mathrm{~m}$ w.e. $\mathrm{a}^{-1}$.

Luthcke and others (2008) found $11.6 \pm 0.7 \mathrm{Gta}^{-1}$ of the mass loss from GRACE data (mascon region 10) for 200307. Mascon 10 includes the YIF as well as large glacier systems such as Malaspina Glacier and large parts of Glacier Bay. Our results indicate that $25 \%$ or $2.89 \pm 0.03 \mathrm{Gta}^{-1}$ of the mass loss of this GRACE mascon came from the YIF.

The results of the five studies are summarized in Figure 7. We show corrected as well as uncorrected results for comparison. When we compared equal methods, we did not include adjustments for the floating tongue. Our results show significantly higher volume change rates than all previous studies.

\section{Partitioning of volume loss}

Yakutat Glacier loses mass by both surface ablation and calving. Surface ablation is directly influenced by climate. However, dynamic adjustments of the glacier surface can also lead to changing surface mass balance, even under a constant climate. To illustrate this effect, the mean thickness change between 2000 and 2010 was -39 m. A mass-balance gradient of $0.0046 \mathrm{a}^{-1}$ (estimated from unpublished massbalance data by the authors) results in a decrease in the surface mass balance of $0.18 \mathrm{ma}^{-1}$, due solely to this change in surface elevation. In contrast, ice loss from calving results from dynamic effects and is only indirectly linked to climate. At Yakutat Glacier, large calving events have been episodic in nature, with large tabular sections of the floating tongue periodically breaking away, interspersed with long periods (on the order of months to years) of relative quiescence. The terminus can then steadily advance until the next calving episode. Although tidewater glaciers experience similar patterns of calving retreat followed by slow advance, this periodicity occurs over much shorter time periods, usually days or weeks ( $\mathrm{O}^{\prime}$ Neel and others, 2003; Amundson and others, 2008).

The long-term episodic nature of lake calving leads to a ratio of surface mass balance vs calving flux that fluctuates significantly with time. In our study, for the periods 2000-07 and $2007-10$, calving accounted for $7.9 \%$ and $16.8 \%$ of the total mass loss respectively.

\section{Comparison of Yakutat Icefield glaciers}

Currently, two of the six glaciers of the YIF are exposed to calving dynamics: Yakutat Glacier (42\% of the icefield) and Battle Glacier (18\%). Yakutat Glacier has been a lacustrine glacier for at least a century (see Fig. 2, 1903), with the largest retreat of the YIF, whereas Battle Glacier has only recently become a lake-calving glacier, with almost no terminus retreat since 1903. The highest thinning rates

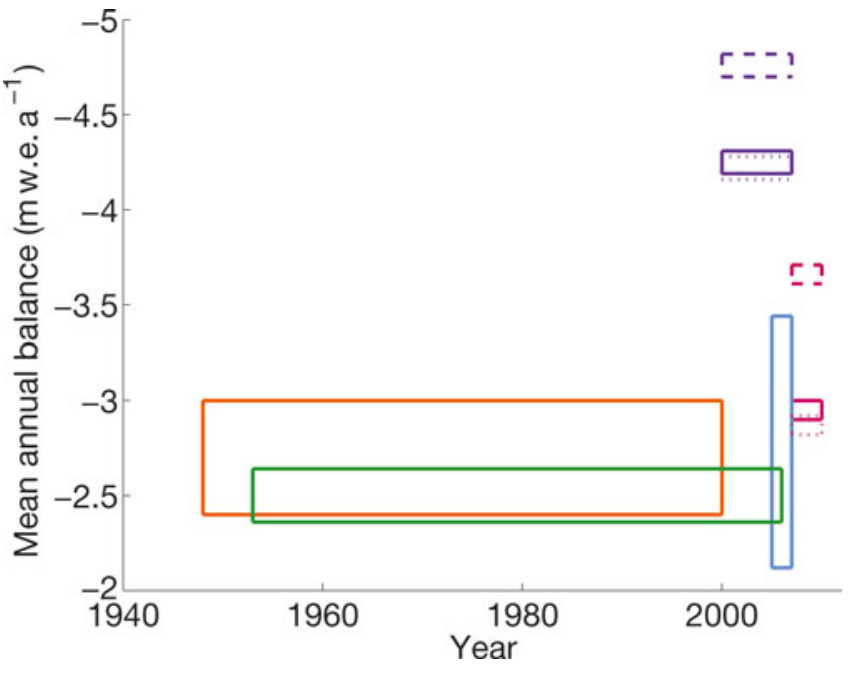

Fig. 7. Area-averaged mass balance for Yakutat Glacier for different years by various authors. The height of the box delineates the uncertainty of the value. Results from our study are depicted by a solid purple box (2000-07) and by a solid red box (2007-10) for DEM differences uncorrected for the floating tongue. Dashed boxes include corrections for the floating tongue in terms of ice loss $(\mathrm{MB})$, and dotted boxes are corrected with respect to mass loss of the glacier-lake system (SLR). Earlier DEM differencing studies are shown in orange (Larsen and others, 2007, 1948-2000) and in green (Berthier and others, 2010, 1953-2006). The data from a laser altimetry study by Arendt and others (2008, 2005-07) are shown in blue.

(2000-10) are found on lake-calving Yakutat Glacier. Battle Glacier and land-terminating East Nunatak have the third and second largest thinning rates respectively (Table 1). The remaining land-terminating glaciers generally are thinning at lower but still significant rates. Yakutat, East Nunatak and West Nunatak glaciers have experienced terminus retreats exceeding $10 \mathrm{~km}$ since 1903 . We note that they have all been exposed to calving during all or part of the last century.

\section{Evolution and collapse of the icefield}

Yakutat Glacier began retreating from its LIA maximum sometime during the 19th century, but the rate of retreat has accelerated since 1903 (Fig. 6). Total retreat between 1903 and 2010 was $15 \mathrm{~km}$. Retreat rates have not been constant, possibly due to changing climate conditions, the episodic nature of calving at Yakutat Glacier, and lake geometry. Bathymetry (unpublished data by authors) shows a relatively shallow sill $(150 \mathrm{~m})$ across the lake at the narrowest part of the lake, compared to depths of $325 \mathrm{~m}$ at the 2010 terminus. The pinning of the narrows and shallower water may have inhibited calving, thereby helping to stabilize the terminus during the period 1960-80. This sill now entraps the large tabular icebergs that have recently calved from Yakutat Glacier from floating further down-lake (Fig. 6b).

The ice divide on the east branch of Yakutat Glacier is currently (2010) lower in elevation than on the west branch. In 1903 the opposite was the case, with the ice divide on the east branch at a higher elevation (Fig. 6a). The lowering of the east branch divide may be connected to tidewater glacier dynamics, since the ice divide is shared with West Nunatak Glacier. While it was a tidewater glacier, Nunatak Glacier could draw down ice faster, thus causing the ice divide to thin more rapidly on the east than on the west branch. 


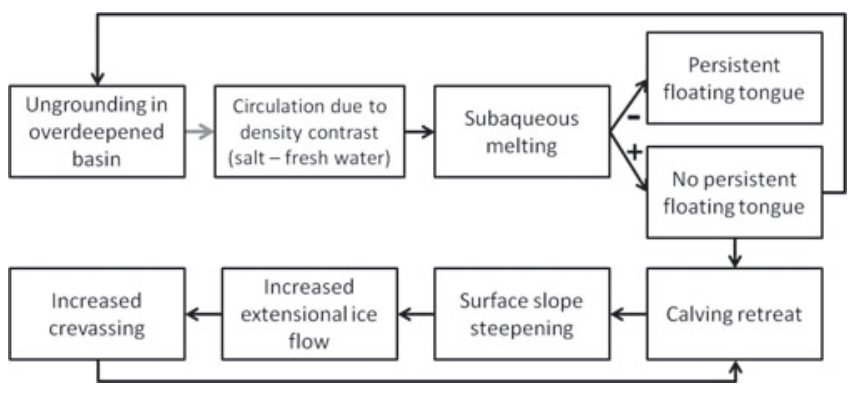

Fig. 8. Positive feedback mechanisms when a glacier retreats into an overdeepened basin. As the glacier becomes ungrounded due to thinning, the density contrast between warm ocean water and fresh, cold subglacial runoff creates buoyancy-driven circulation in a tidewater system that results in submarine melting. This link (gray arrow) is broken in a lacustrine glacier system, because the freshwater density contrast will likely not be strong enough to trigger circulation, and water temperatures are too cold to cause subaquatic melting.

Our results clearly show that the entire YIF is in rapid decline. With little or no accumulation zones (AAR mostly $<0.05)$, these glaciers are destined to continue their decline into the foreseeable future. Even if the current climate trends are reversed, it will take a substantial change in the regional ELA before these glaciers can begin growing again. We now address the question of how the YIF formed in the first place, and what then led to its collapse, by drawing on published glacial geology (e.g. Barclay and others, 2001), considerations of terrain and the IBC maps of 1903.

A 'typical' alpine glacier with zero mass balance will have an AAR value between 0.5 and 0.7 (Paterson, 1994, ch. 3), with coastal Alaska favoring the latter value (Meier and Post, 1962). The YIF itself does not have a highelevation accumulation area. Thus, the original LIA YIF must have either been fed from nearby regions or been subject to a much colder climate or both. Events leading to the post-LIA collapse of the YIF must have preceded the first mapping of the region, because by 1903 the ice divides had already dropped to near the current ELA threshold (Fig. $6 a)$, so that the AAR was probably well below that needed to sustain the glaciers. We suggest that the YIF is now a remnant icefield. Such remnants exist nearby in Glacier Bay (i.e. Burroughs Glacier) and also in Russell Fjord (Orange Glacier).

During the early 17th century, the east lobe of Hubbard Glacier (a major tidewater glacier to the northwest of Russell Fjord; Fig. 2) was at its maximum extent and spilled into the south end of Russell Fjord (Barclay and others, 2001). During the same period, Nunatak and Hidden Glaciers advanced into Russell Fjord, where they were then dammed by the east lobe of Hubbard Glacier. By the late 18th century, glacier ice had filled the entire southern part of Russell Fjord, with a terminus lobe advancing onto land beyond the south end of the fjord. Abetted by the generally cooler LIA climate, these circumstances could have led to the growth of the YIF: ice from Nunatak and Hidden Glaciers would have backed up because of the Hubbard dam, thereby increasing the height of the YIF ice divides and glacier elevations overall. Ice spilling over to the southeast could have fed the other branches of the YIF. By the end of the 18th century, the main and east lobes of Hubbard Glacier had retreated, and Nunatak Glacier became the primary source of ice into Russell Fjord. The retreat of
Hubbard Glacier caused the ice-flow direction to reverse in the northwest arm of Russell Fjord. Ice started to retreat from the south end of Russell Fjord in the late 18th century (Barclay and others, 2001). Nunatak and probably Hidden Glaciers were tidewater glaciers at this time, and a calving retreat likely ensued with the waning of LIA climate conditions. Historically, in the early 1900s, East and West Nunatak Glaciers were still connected as one tidewater glacier calving into Nunatak Fjord (Tarr and Martin, 1914). However, rapid retreat eventually separated the two arms, with both retreating onto land. The changing climate and the retreat of Nunatak and Hidden Glaciers eventually led to the collapse and current condition of the YIF. Such a scenario is not without precedent: Glacier Bay is a prime example where LIA advance and expansion of the main trunk glaciers led to the formation of large peripheral glaciers and ice fields, which subsequently collapsed once the main trunk glacier retreated (Larsen and others, 2007).

Other potential sources of ice for the growth of the YIF during the LIA are Art Lewis and Vern Ritchie Glaciers, which lie north of the YIF (Fig. 2). Both these glaciers have high-elevation accumulation areas and their growth during the LIA may have been sufficient to allow ice to spill over and feed Nunatak and Battle Glaciers (Fig. 2). Given the high precipitation rates in this region, the climate during the LIA may have been sufficiently colder to allow the YIF to grow. However, since the current ELA is essentially at or above the current ice divides, the difference would have to have been considerable if this was the only operative process. We also point out that growing ice fields are subject to a positive feedback effect, which would allow them to continue to grow, perhaps rapidly. This instability is similar, but reversed in sign, to what is currently happening.

\section{Tidewater vs lacustrine glacier}

Tidewater glaciers experience calving rates up to an order of magnitude greater than lake-calving glaciers, ice speeds are more than an order of magnitude higher and near-terminus surface slopes are steeper. In the following we propose a hypothesis to explain these differences.

We initially assume a temperate glacier in an overdeepened basin near its maximum extent in steady state, with the terminus exposed to calving. If the glacier experiences sufficient thinning, portions of the terminus area can become ungrounded. If the ungrounding allows a cavity to form, a tidewater system will likely react differently than a lacustrine system (Fig. 8). In a tidewater situation, a submarine cavity would rapidly be exposed to high basal melt rates, as water circulation driven by subglacial freshwater discharge would transport warm ocean water to the base of the ice. Measurements in Alaska (Motyka and others, 2003b) and Greenland (Motyka and others, 2011) show that such melt rates can be well in excess of $1 \mathrm{~m} \mathrm{~d}^{-1}$. Thinning due to subglacial melt then decreases the stability of the terminus and ice calves back to the grounding line. Indeed, floating termini are rarely observed in temperate tidewater glaciers, and, when present, appear to be a temporary and unstable feature (Walter and others, 2010). This rapid retreat then steepens the near-terminus surface slope, leading to increased extensional ice flow. Faster ice flow causes increased crevassing, which in turn helps drive calving rates (Benn and others, 2007). The glacier thus experiences high calving rates, high flow rates with large extensional gradients, and heavy crevassing. Higher velocities at 
tidewater glaciers are also facilitated by the denser water at their termini, which leads to lower effective pressures for a given ice thickness (Van der Veen, 2002).

In the case of a lacustrine glacier, cavities formed by ungrounding can exist for an extended period of time. The subglacial discharge is not buoyant compared to the lake water, since the temperature and density differences are small. The lake water temperature in Harlequin Lake varies between 0.5 and $1.5^{\circ} \mathrm{C}$, which appears to be typical of other proglacial lakes (Boyce and others, 2007). These lower temperatures are a result of the lake being a closed system with icebergs in it. Thus, water circulation and heat exchange are generally minimal. Therefore, steep surface slopes do not develop and a positive feedback mechanism between retreat, surface slope, extensional thinning and crevasses is not established. The part of the glacier that is decoupled from its bed appears to be stable for an extended period of time. Indeed floating termini are commonly observed in temperate lake-calving glaciers. Lacustrine glaciers can form floating tongues that are stable for months to years or longer, whereas tidewater glaciers in the same climate are unable to maintain a floating terminus, which can lead to steeply sloped terminus areas and attendant high ice fluxes.

Eventually, continued thinning of a lake-calving terminus and lake-level rise can lead to episodic calving of large tabular icebergs, but these events may occur as infrequently as once a year. In tidewater systems, calving occurs much more frequently, often on a daily to weekly basis, abetted by tidal flexure as well as extensional thinning and crevassing.

\section{CONCLUSIONS}

The Yakutat Ice Field has experienced dramatic thinning: $3.52 \pm 0.05 \mathrm{~m}$ w.e. $\mathrm{a}^{-1}$ between 2000 and 2010. With an AAR of 0.04 (in 2007), the majority of the YIF is well below the ELA, exposing most of the glacier area to negative surface balance. The entire ice field experiences thinning, and the resulting lowering of the ice surface leads to increasingly negative surface balances, even under a constant climate. We thus expect the YIF to continue thinning and retreating, and predict the eventual disappearance of most of the ice field, even without additional warming.

The evolution of the YIF and transformation into a remnant ice field appears to have been fostered by a combination of factors, including a colder LIA climate, thickening of Nunatak and Hidden Glaciers and other YIF glaciers as a result of Hubbard Glacier damming Russell Fjord, and spillover of glacier ice from Art Lewis and Vern Ritchie Glaciers. The post-LIA collapse was driven by the tidewater calving retreats of Nunatak and Hidden Glaciers, the lake-calving retreat of Yakutat Glacier, a warming climate, and the Bodvarsson feedback mechanism.

The YIF comprises both land-terminating and lakecalving glaciers, the largest being lake-calving Yakutat Glacier, covering $42 \%$ of the YIF. Yakutat Glacier was able to build and maintain a $17.2 \mathrm{~km}^{2}$ floating tongue for over a decade. Corrections have to be applied to convert floatingtongue elevation changes to thinning rates. Ignoring this effect leads to an underestimate of ice loss and an overestimate of mass loss of the glacier-lake system. Yakutat Glacier has been exposed to calving retreat for more than a century. Calving rates are highly variable, with periods of rapid retreat followed by periods of relative stability. The most recent period of rapid retreat began in 2010, when the floating tongue disintegrated into large tabular icebergs, a process that is common on other lakecalving systems (Boyce and others, 2007). The contribution of calving to total mass loss increased from 7.9\% (2000-07) to $16.8 \%$ (2007-10). Yakutat Glacier currently experiences larger mass loss than land-terminating glaciers of the YIF. This points to the importance of mass loss through calving, not only into the ocean, but also into proglacial lakes. The latter is potentially important for mass-balance studies of the Greenland ice sheet, where lakes are common, especially along its western perimeter.

Tidewater glaciers in the vicinity of the YIF are exposed to a similar climate, but they neither form nor maintain a stable floating tongue nor calve large tabular icebergs, even when retreating into overdeepened basins. We hypothesize that the different calving behavior is caused by the presence or absence of submarine melt as the glacier retreats into an overdeepening. In the case of a tidewater glacier, submarine melt can be large, leading to instability and retreat. In a lacustrine system, subaquatic melt is negligible, allowing floating tongues to form.

\section{ACKNOWLEDGEMENTS}

A. Post provided terminus outlines based on his air photos. E. Berthier provided mass-balance data specifically extracted to our area. M. Fahnestock provided code for the image correlation analysis. We thank A. Aschwanden, W. Dryer, M. Habermann, S. Herreid, J. Hulth, A. Johnson, J. Kennedy, C. Kienholz, R. McNabb, D. Podrasky, J. Young and L. Zirnheld for assistance with fieldwork. CH2M HILL Polar Services provided logistics support, Bill Lucey and Tim Ross supported the work in Yakutat, and Temsco Helicopters and Alsek Air provided air charter services. The SPOT-5 images used for DEM differencing were provided by the SPIRIT program (Centre National d'Etudes Spatiales, France). Funding was provided by the US National Science Foundation (NSF) Office of Polar Programs (OPP) grant ARC 0806463. Additional funding was provided by the Geophysical Institute, University of Alaska Fairbanks. We thank R. Naruse, an anonymous reviewer and the scientific editor, T. Scambos, for thorough reviews that helped to focus the manuscript.

\section{REFERENCES}

Amundson JM, Truffer M, Lüthi MP, Fahnestock M, West $M$ and Motyka RJ (2008) Glacier, fjord, and seismic response to recent large calving events, Jakobshavn Isbræ, Greenland. Geophys. Res. Lett., 35(22), L22501 (doi: 10.1029/2008GL035281)

Arendt AA, Echelmeyer KA, Harrison WD, Lingle CS and Valentine VB (2002) Rapid wastage of Alaska glaciers and their contribution to rising sea level. Science, 297(5580), 382-386 (doi: 10.1126/science.1072497)

Arendt AA, Luthcke SB, Larsen CF, Abdalati W, Krabill WB and Beedle MJ (2008) Validation of high-resolution GRACE mascon estimates of glacier mass changes in the St Elias Mountains, Alaska, USA, using aircraft laser altimetry. J. Glaciol., 54(188), 778-787 (doi: 10.3189/002214308787780067)

Barclay DJ, Calkin PE and Wiles GC (2001) Holocene history of Hubbard glacier in Yakutat Bay and Russell Fjord, southern Alaska. Geol. Soc. Am. Bull., 113(3), 388-402 (doi: 10.1130/ 0016-7606(2001)113<0388:HHOHGI>2.0.CO;2) 
Benn DI, Warren CW and Mottram RH (2007) Calving processes and the dynamics of calving glaciers. Earth-Sci. Rev., 82(3/4), 143-179 (doi: 10.1016/j.earscirev.2007.02.002)

Berthier E, Schiefer E, Clarke GKC, Menounos B and Rémy F (2010) Contribution of Alaskan glaciers to sea-level rise derived from satellite imagery. Nature Geosci., 3(2), 92-95 (doi: 10.1038/ngeo737)

Bodvarsson G (1955) On the flow of ice-sheets and glaciers. Jökull, 5, 1-8

Bøggild CE, Olesen OB, Ahlstrøm AP and Jørgensen P (2004) Automatic glacier ablation measurements using pressure transducers. J. Glaciol., 50(169), 303-304 (doi: 10.3189/ 172756504781830097)

Boyce ES, Motyka RJ and Truffer M (2007) Flotation and retreat of a lake-calving terminus, Mendenhall Glacier, southeast Alaska, USA. J. Glaciol., 53(181), 211-224 (doi: 10.3189/ 172756507782202928)

Cox LH and March RS (2004) Comparison of geodetic and glaciological mass-balance techniques, Gulkana Glacier, Alaska, U.S.A. J. Glaciol., 50(170), 363-370 (doi: 10.3189/ 172756504781829855)

Cutler PM, Mickelson DM, Colgan PM, MacAyeal DR and Parizek BR (2001) Influence of the Great Lakes on the dynamics of the southern Laurentide Ice Sheet: numerical experiments. Geology, 29(11), 1039-1042

Dykes RC, Brook MS and Winkler S (2010) The contemporary retreat of Tasman Glacier, Southern Alps, New Zealand, and the evolution of Tasman proglacial lake since AD 2000. Erdkunde, 64(2), 141-154 (doi: 10.3112/erdkunde.2010.02.03)

Eisen O, Harrison WD and Raymond CF (2001) The surges of Variegated Glacier, Alaska, U.S.A., and their connection to climate and mass balance. J. Glaciol., 47(158), 351-358 (doi: 10.3189/172756501781832179)

Funk M and Röthlisberger H (1989) Forecasting the effects of a planned reservoir which will partially flood the tongue of Unteraargletscher in Switzerland. Ann. Glaciol., 13, 76-81

International Boundary Commission (IBC) (1952) International boundary between United States and Canada from Cape Muzon to Mount St. Elias. Scale: 1:250,000. International Boundary Commission, Ottawa

Korona J, Berthier E, Bernard M, Rémy F and Thouvenot E (2009) SPIRIT. SPOT 5 stereoscopic survey of polar ice: reference images and topographies during the fourth International Polar Year (2007-2009). ISPRS J. Photogramm. Remote Sens., 64(2), 204-212 (doi: 10.1016/j.isprsjprs.2008.10.005)

Larsen CF (2010) IceBridge UAF Lidar Profiler L1B geolocated surface elevation triplets, [29 August 2010] Version 1. NASA Distributed Active Archive Center, National Snow and Ice Data Center, Boulder, CO http://nsidc.org/data/ilakp1b.html

Larsen CF, Motyka RJ, Freymueller JT, Echelmeyer KA and Ivins ER (2005) Rapid viscoelastic uplift in southeast Alaska caused by post-Little Ice Age glacial retreats. Earth Planet. Sci. Lett., 237(3-4), 548-560 (doi: 10.1016/j.epsl.2005.06.032)

Larsen CF, Motyka RJ, Arendt AA, Echelmeyer KA and Geissler PE (2007) Glacier changes in southeast Alaska and northwest British Columbia and contribution to sea level rise. J. Geophys. Res., 112(F1), F01007 (doi: 10.1029/2006JF000586)

Luthcke SB, Arendt AA, Rowlands DD, McCarthy JJ and Larsen CF (2008) Recent glacier mass changes in the Gulf of Alaska region from GRACE mascon solutions. J. Glaciol., 54 (188), 767-777 (doi: 10.3189/002214308787779933)

Meier MF and Post AS (1962) Recent variations in mass net budgets of glaciers in western North America. IASH Publ. 58 (Symposium at Obergurgl 1962 - Variations of the Regime of Existing Glaciers), 63-77

Meier MF and 7 others (2007) Glaciers dominate eustatic sea-level rise in the 21st century. Science, 317(5841), 1064-1067 (doi: 10.1126/science.1143906)

Motyka RJ, Hunter L, Echelmeyer KA and Connor C (2003a) Submarine melting at the terminus of a temperate tidewater glacier, LeConte Glacier, Alaska, U.S.A. Ann. Glaciol., 36, 57-65 (doi: 10.3189/172756403781816374)

Motyka RJ, O'Neel S, Connor CL and Echelmeyer KA (2003b) 20th century thinning of Mendenhall Glacier, Alaska, and its relationship to climate, lake calving, and glacier run-off. Global Planet. Change, 35(1-2), 93-112 (doi: 10.1016/S0921-8181 (02)00138-8)

Motyka RJ, Fahnestock M and Truffer M (2010) Volume change of Jakobshavn Isbræ, West Greenland: 1985-19972007. J. Glaciol., 56(198), 635-646 (doi: 10.3189/ $002214310793146304)$

Motyka RJ, Truffer M, Fahnestock M, Mortensen J, Rysgaard S and Howat I (2011) Submarine melting of the 1985 Jakobshavn Isbræ floating tongue and the triggering of the current retreat. J. Geophys. Res., 116(F1), F01007 (doi: 10.1029/2009JF001632)

Naruse R and Skvarca P (2000) Dynamic features of thinning and retreating Glaciar Upsala, a lacustrine calving glacier in southern Patagonia. Arct. Antarct. Alp. Res., 32(4), 485-491

O'Neel S, Echelmeyer KA and Motyka RJ (2003) Short-term variations in calving of a tidewater glacier: LeConte Glacier, Alaska, U.S.A. J. Glaciol., 49(167), 587-598 (doi: 10.3189/ 172756503781830430)

Paterson WSB (1994) The physics of glaciers, 3rd edn. Elsevier, Oxford

Pfeffer WT, Harper JT and O'Neel S (2008) Kinematic constraints on glacier contributions to 21 st-century sea-level rise. Science, 321(5894), 1340-1343 (doi: 10.1126/science.1159099)

Post A, O'Neel S, Motyka RJ and Streveler G (2011) A complex relationship between calving glaciers and climate. Eos, 97(37) 305-306 (doi: 10.1029/2011EO370001)

Radić V and Hock R (2011) Regionally differentiated contribution of mountain glaciers and ice caps to future sea-level rise. Nature Geosci., 4(2), 91-94 (doi: 10.1038/ngeo1052)

Raup B and 11 others (2007) Remote sensing and GIS technology in the Global Land Ice Measurements from Space (GLIMS) Project. Comput. Geosci., 33(1), 104-125 (doi: 10.1016/j.cageo.2006. 05.015)

Rignot E, Rivera A and Casassa G (2003) Contribution of the Patagonian icefields of South America to sea level rise. Science, 302(5644), 434-437 (doi: 10.1126/science.1087393)

Rodríguez E, Morris CS and Belz JE (2006) A global assessment of the SRTM performance. Photogramm. Eng. Remote Sens., 72(3), 249-260

Rolstad C, Haug T and Denby B (2009) Spatially integrated geodetic glacier mass balance and its uncertainty based on geostatistical analysis: application to the western Svartisen ice cap, Norway. J. Glaciol., 55(192), 666-680 (doi: 10.3189/ 002214309789470950)

Scambos TA, Dutkiewicz MJ, Wilson JC and Bindschadler RA (1992) Application of image cross-correlation to the measurement of glacier velocity using satellite image data. Remote Sens. Environ., 42(3), 177-186 (doi: 10.1016/0034-4257(92)90101-O)

Solomon S and 7 others eds. (2007) Climate change 2007: the physical science basis. Contribution of Working Group I to the Fourth Assessment Report of the Intergovernmental Panel on Climate Change. Cambridge University Press, Cambridge

Stuefer M, Rott H and Skvarca P (2007) Glaciar Perito Moreno, Patagonia: climate sensitivities and glacier characteristics preceding the 2003/04 and 2005/06 damming events. J. Glaciol., 53(180), 3-16 (doi: 10.3189/172756507781833848)

Tarr RS and Martin L (1914) Alaskan glacier studies of the National Geographic Society in the Yakutat Bay, Prince William Sound and Lower Copper River regions. National Geographic Society, Washington, DC

Van der Veen CJ (2002) Calving glaciers. Progr. Phys. Geogr., 26(1), 96-122 (doi: 10.1191/0309133302pp327ra)

Walter F, O'Neel S, McNamara DE, Pfeffer T, Bassis J and Fricker HA (2010) Iceberg calving during transition from grounded to floating ice: Columbia Glacier, Alaska. Geophys. Res. Lett.,37(15), L15501 (doi: 10.1029/2010GL043201) 
Warren C and Aniya M (1999) The calving glaciers of southern South America. Global Planet. Change, 22(1-4), 59-77

Warren CR and Kirkbride MP (2003) Calving speed and climatic sensitivity of New Zealand lake-calving glaciers. Ann. Glaciol., 36, 173-178 (doi: 10.3189/172756403781816446)

Warren CR, Greene DR and Glasser NF (1995) Glaciar Upsala, Patagonia: rapid calving retreat in fresh water. Ann. Glaciol., 21, 311-316

Warren C, Benn D, Winchester V and Harrison S (2001) Buoyancy-driven lacustrine calving, Glaciar Nef, Chilean Patagonia. J. Glaciol., 47(156), 135-146 (doi: 10.3189/ 172756501781832403)

\section{APPENDIX}

For most of the icefield, elevation-change $(\Delta Z)$ data from the differenced DEM can be used directly to calculate ice volume change and a mean thinning rate, $\Delta H / \Delta t$. However, the terminus of Yakutat Glacier is floating and thus has to be treated separately. We identified four zones: (1) grounded ice, (2) free-floating ice, (3) the transition zone in between and (4) the retreated zone. To differentiate between these zones, we derived profiles along several transects from the grounded ice to the floating tongue from the differenced DEMs (Fig. 4c and d). The largest $\Delta Z$ were found in the area of the grounding line, followed by a steep increase (more negative to less negative) in a transition zone. The boundary between the transition zone and the freefloating part was determined by picking points on each transect by hand (Fig. $4 \mathrm{f}$ and g). The mean $\Delta Z$ of points describing the grounding line was $-66.6 \mathrm{~m}$ for the first period (2000-07), and $-18.1 \mathrm{~m}$ (west branch) and $-23.0 \mathrm{~m}$ (east branch) for the second period (2007-10, separated by / from here on). For the border between the transition zone and the free-floating part we found a mean $\Delta Z$ of $-6.9 \mathrm{~m} /$ $0.4 \mathrm{~m} /-1.8 \mathrm{~m}$. Once separated, $\Delta Z$ in each zone were weighted differently. In the first zone, the grounded ice, $\Delta Z$ directly reflect $\Delta H$, and no further corrections were needed.

The transition zone was handled slightly differently for the two time periods. For period one we applied a linear trend extending from the grounding line, starting with a $\Delta Z$ of $-66.6 \mathrm{~m}$, to the free-floating line with a $\Delta Z$ of $-6.9 \mathrm{~m}$, which was weighted ten times to account for the buoyancy of ice in fresh water (measured $\Delta Z$ of $-6.9 \mathrm{~m}$ translate to $\Delta H$ values of $-69 \mathrm{~m})$. For period two, the elevation change at the freefloating line was sufficiently different for the two branches to justify defining two separate transition zones, one for the faster-flowing west branch and one for the east branch. Measured $\Delta Z$ at the upstream end of the free-floating part were 0.4 and $-1.8 \mathrm{~m}$ (Fig. $4 \mathrm{f}$ and $\mathrm{g}$ ). These would be interpreted as thickness changes of +4.0 and $-18.0 \mathrm{~m}$, respectively for the east and west branches, and lead to unrealistic thickness change gradients from the grounding line to the free-floating part $>2 \mathrm{~km}$ farther downstream. Recognizing the subjectivity in picking these values from transect profiles, and the large potential errors due to the hydrostatic compensation, we chose a thickness change value at the free-floating part of $-21.0 \mathrm{~m}$, which corresponds to the mean of the grounding line values of both branches.

The third zone, the floating tongue, was assumed to be in hydrostatic equilibrium, with an ice density of $900 \mathrm{~kg} \mathrm{~m}^{-3}$ and freshwater density of $1000 \mathrm{~kg} \mathrm{~m}^{-3}$. Only one-tenth of the actual $\Delta H$ was accounted for in $\Delta Z$ data due to buoyancy. Hence, the value of $>-6.9 \mathrm{~m}$ for the first period was corrected to $-69 \mathrm{~m}$ for hydrostatic equilibrium. For the second period we estimated a value of $-21 \mathrm{~m}$, as explained above. Smaller values were truncated to -69 and $-21 \mathrm{~m}$ respectively to prevent overestimation. Similarly, values greater than zero were set to zero, assuming no thickening in the ablation area.

The fourth zone, the area of terminus retreat, was identified on Landsat images. The retreated area was then cut out on the earlier DEM, and the elevation above lake level was multiplied by 10 to obtain the actual ice thickness of the retreated part. Some values near the lateral margin indicated an ice thickness of $>300 \mathrm{~m}$, which is likely due to a failure of the free-floating assumption. These values were corrected. All four zones changed over time and were determined separately for 2000-07 and 2007-10.

Correcting for a floating tongue introduces an additional source of uncertainty. For the second time period (SPOT 2007-10), $\sim 2.2 \%$ of the entire surface area of the YIF was part of the floating zone. For this area, the uncertainty described in the 'Digital elevation model differencing' section is increased by an order of magnitude, due to the multiplication by 10 to derive $\Delta H$ from $\Delta Z$ data. The 2000 SRTM DEM was obtained in winter with a frozen, and thus measurable, lake level, resulting in negligible uncertainties. For the second period, we assumed a lake level of $28 \mathrm{~m}$ a.s.l. based on our lake-level measurements using GPS and pressure-sensor records for summer seasons 2009-11. A $1 \mathrm{~m}$ error in lake level translates to a volume change of $\sim 0.033 \mathrm{~km}^{3}$ (or $\pm 6.4 \%$ of the retreated volume). For the transition zone $(1.5 \%)$ we estimated a factor 5 increased error, compared to grounded ice. Equivalent corrections apply for the first time period (2000-07) for the floating zone covering a surface area of $1.2 \%$ and a $2.0 \%$ transition zone. The adjustments for the retreated part entail further errors. For the first period, eliminating unrealistic values around the edges resulted in a volume decrease of $0.165 \mathrm{~km}^{3}$ or $0.7 \%$ of the total volume change, and a volume increase of $0.003 \mathrm{~km}^{3}$ for the second period. Volume loss of the retreated part is also affected by uncertainties in lake level. Combining the uncertainties of the retreated part (2007-10) results in a total volume uncertainty of $0.035 \mathrm{~km}^{3}$ or $0.4 \%$ of the total volume loss of the YIF. These additional uncertainties increase the volume uncertainty of Yakutat Glacier from $0.12 \mathrm{~km}^{3}$ to $0.13 \mathrm{~km}^{3}$, but do not influence the volume uncertainty of the YIF. 